\title{
5 Euro: The Career of a European Neologism in German Press Texts (1995-1999)
}

DIETER HERBERG

\section{Introduction}

As part of the larger topic of 'Attitudes Towards Europe', this chapter deals with the sub-topic of the European monetary union. It will focus on the career of the name for the common currency adopted by the members of the Economic and Monetary Union (EMU) - Euro - and its rendition in German press texts from 1995 to 1999.

We have chosen a lexicological approach starting with the competing designations of the expressions based on the currency name Euro, analysing the word formations appearing with this neolexeme as well as its collocations in three chronological sections. The aim is to demonstrate the communicative power behind the various linguistic realisations of the theme word Euro: Not only is it regarded merely as the name for the common currency of the members of the EMU; instead, on a larger scale it may act as a crystallisation nucleus towards the concept of an integrated Europe.

This aim is reflected in the structure of the chapter: We will first outline the factual background as necessary for the understanding of the subject; secondly, we will explain the methods. Thirdly, we will describe the grammatical and morphological properties of the lexeme Euro. The final part contains the analytic and interpretative parts and presents the lexical evidence for each of the chronological sections. 
Facts

\section{European Economic and Monetary Union (EMU)}

Although a full rendering of the history of European integration in all its aspects would exceed the scope of this chapter, let us take a quick glance at the development of the European Economic and Monetary Union (EMU) and its stages, the introduction of the Euro within the framework of the EMU so far being the biggest event in the history of European integration.

The EMU is being brought about in three stages. The first stage commenced on 1 July 1990, when all restrictions on the movement of capital between EU member states were abolished.

The second stage started on 1 January 1994 and ended 31 December 1998. In this stage, the EU member states were expected to meet the economic convergence criteria in order to be eligible for participation in the monetary union. The convergence criteria were laid out in the Maastricht Treaty of 1992, with the following stability aims: price stability; balanced public finances (absence of an excessive government deficit); low longterm interest rates and exchange rate stability. On the basis of the statistical data for 1997, the European Council - the assembly of the Heads of State or Government of the fifteen member states of the European Union and the President of the European Commission - recommended in early May 1998 that from the beginning of 1999 the following eleven countries should participate in the Economic and Monetary Union: Austria, Belgium, Finland, France, Germany, Ireland, Italy, Luxembourg, The Netherlands, Portugal, Spain. The United Kingdom and Denmark, although meeting the convergence criteria, decided not yet to adopt the new currency from 1999 on, thus exercising their special right to opt out afforded by the Maastricht Treaty.

On 1 January 1999 the third and final stage commenced with the implementation of a single monetary policy under the responsibility of the European System of Central Banks (ESCB) and the gradual changeover to the Euro as the common currency of the member countries. There will be a transitional period (1 January 1999 - 31 December 2001) where banking is possible both in Euro and the national currencies. Circulation of Euro coins and banknotes will start 1 January 2002. From 1 March 2002 national banknotes and coins will cease to be legal tender. 
The Euro - its Name and History

It has been a long way to the currency unit 'Euro', its immediate predecessor being the 'European Currency Unit', better known in its short form 'Ecu/ECU'. Unlike the Euro, the ECU, which had been introduced on 13 March 1979, had always been an artificial or 'ledger' currency.

It had been established as a common basket currency to accommodate the fixed, but variable exchange rates of the national currencies within the framework of the European Monetary System.

During the preparation stage for the creation of a common European currency for the members of the Economic and Monetary Union, another debate arose when it came to finding a name for the new common currency. Although the original EU treaty proposed to simply keep the name 'ECU', this turned out to be a highly controversial issue within the discussion, as the German partners in particular opposed ECU as the name for the new currency. This name would not appeal to German citizens, who were said to be mostly sceptical towards the monetary union anyway. Moreover, another argument against the use of 'ECU' was to be found in the official German version of the EU treaty, where 'ECU' was spelt with capital letters, thus being not a name but merely an abbreviation for 'European Currency Unit'. The new currency, however, should have a proper name if it was to be accepted by the citizens. But the controversies slowly died down. After a passing predilection for 'Franc' ('Die Euro-Währung wird wohl Franken heißen' ['The Euro-currency will most probably be named Franc'] Berliner Zeitung, 29 May 1995, p. 7), 'Euro', the proposal suggested by the then German Finance Minister Theo Waigel during a meeting of the EU finance ministers in October 1995 in Valencia gained ground. The first occurrence of the word 'Euro' within the IDS corpora refers to this meeting:

Wie das neue Geld heißen wird, darüber gab es einen aussichtsreichen Vorschlag, der immer wieder auf den Gängen des Sitzungssaales kommentierte "Euro". (die tageszeitung, 2 October 1995, p. 6)

[There has been a promising proposal for the name of the new currency, judged by the comments in the conference room: "Euro".]

Shortly after that date, during the Madrid Summit meeting on $15 / 16$ December 1995, the EU Heads of State or Government agreed upon the name 'Euro' for the future common currency, for it was meeting essential 
criteria such as being acceptable to the citizens, easy to understand and to pronounce, and not biased towards any particular nation.

This decision also put an end to the - however short-lived - discussion of another proposal, mostly designed to build up trust: to combine the name 'Euro' with the national currency denominators, thus naming it 'Euromark', 'Eurofranc', and so on. Finally, in 1996, a name was also given to the coins to be used for small change - 'Cent' or - more precisely - 'Eurocent'. One Euro equals 100 Cent. Thus, a neutral name had been found also for the smaller denomination. Unlike the neologism Euro, Cent - deriving from the Latin word for 'one hundred' centum - is already used in various countries as a name for the smaller denomination of their currency.

A final remark about the denominations: there will be seven banknotes (of 5, 10, 20, 50, 100, 200 and 500 Euro) and eight coins (of 1, 2, 5, 10, 20 and 50 cent and of 1 and 2 Euro).

Now and then, the name Euro has also been subjected to (linguistic) criticism. For instance, the Deutsche Akademie für Sprache und Dichtung (German Academy of Language and Literature) criticised Euro as an Unwort [nonsense word]:

weil das Abhacken der letzten Silbe einem historisch verwurzelten Begriff wie "Europa" nicht gerecht werde. (Fachdienst Germanistik 4/1998, p. 7)

[because to simply chop off the last syllable means to disregard the deeply rooted historical context of a word like "Europe".]

However, such critical comments ceased fairly quickly. For Euro can indeed be seen as a successful formation, conferring a tangible term on the currency to be shared by several million European citizens. Moreover, the form ending with the vowel $-o$ corresponds to a pattern well established with currency names, cf. Peso, Escudo, Centesimo.

Among the linguistic aspects typical for currency names is the use of signets and abbreviations.

Besides one or more abbreviations, there are special symbols (signets or 'logos') for some currencies; among the best known are the dollar sign $(\$)$ or the symbol used for the Pound Sterling ( $£$ ). The new European currency unit Euro also has its own symbol, chosen at the EU summit in December 1996 in Dublin: $€$.

Closely following a press report of April 1997, in which the European Commission presented the Euro sign to the public, Duden - Der Euro (1998, p. 85) explained the Euro symbol as follows: 
Das Zeichen für den Euro (Euro-Logo, Euro-Signet) stellt eine Kombination aus dem griech. Epsilon als Symbol für die Wiege der europ. Zivilisation, dem Buchstaben E für Europa und den Parallelen (doppelter Querstrich) als Symbol für Stabilität dar. Dieses symbol. Zeichen für den Euro wird voraussichtlich einen ähnl. Bekanntheitsgrad erreichen wie das Dollarzeichen $\$$ und auch in die Standardbelegung von Computer- und Schreibmaschinentastaturen aufgenommen werden.

[The Euro symbol (Euro logo, Euro sign) is a combination of the Greek epsilon symbolising the cradle of European civilisation and the parallel lines (equals sign) symbolising stability. It is expected that the Euro symbol will become as widely known as the dollar sign $\$$ and will soon appear on the standard keyboard layout for computers and typewriters'.]

As far as the abbreviations for currencies are concerned, one has to distinguish between the common abbreviations used by the different nations - for instance DM for Deutsche Mark, Lit for Lira Italiana, FF for Franc Français - and the official abbreviations designed by the ISO (International Organisation for Standardisation), which always consist of three capital letters, such as DEM for Deutsche Mark, ITL for Lira Italiana, FRF for Franc Français and so on. This so-called ISO code is used throughout the whole commerce system, for instance within the giro system and on the foreign exchange markets. The ISO code EUR for Euro was announced in April 1997. Along with this abbreviation, the Euro signet will also be made an ISO standard as the symbol for the new currency.

\section{Method and Approach}

As stated in the introduction to this article, we have chosen a lexicological approach to analyse the dynamic usage of the neolexeme Euro as an example for conscious, standardised lexical change (cf. Wurzel 1994, pp. 98). Apart from striking collocations of the lexeme, our main focus will be on compounds with Euro as one of their constituents. By applying this analysis - or rather, microanalysis - of recent language change we will describe and interpret the changing usage aspects of a neologism acting as a European theme word during a five-year time span ranging from 1995 to 1999.

Here again, we will use the same methods that we applied for the analysis of key words of the Wende era, the German re-unification period (cf. Herberg/Steffens/Tellenbach 1997), i.e. a survey based on a defined text corpus, describing and interpreting the use of the neolexeme Euro and 
its combinations in common language. However, an extensive, sourcebased documentation of the findings would exceed the scope of this article.

As stated above, this chapter presents details of common language usage in the Federal Republic of Germany ranging from the end of 1995 to the beginning of 1999, i.e. from the formation of the currency name Euro to the official introduction of the currency thus designated in the countries of the European Union. In order to describe the details of the changes and special features of language use in relation to certain events in history, it is necessary to structure the investigation period. It will therefore be divided into three chronological sections, each of which is characterised by distinct developments and stages within the framework of the EMU. Each section represents an investigation period of four months, with the sections arranged in order to include also the media coverage of the historical environment of the relevant events, developments and issues:

Period 1:

Decision to assign the name Euro to the new common currency of the European Union (November/December 1995, January/February 1996).

Period 2:

Debate on the fulfilment of the convergence criteria and on the eligibility of the participating countries for membership in the EMU (November/December 1997, January/February 1998).

Period 3:

Introduction of the Euro as 'ledger currency' on 1 January 1999 (November/December 1998, January/February 1999).

Assigning texts to different periods is a proven heuristic instrument to detect and verify changes in language use and word formation in relation to one or more previous or subsequent periods.

This analysis is entirely based on common language as represented in newspaper texts. Common language use, here also including official use, is of particular interest, as it reflects,

die Intentionen und Interpretationen gesellschaftlich wirksamer Kräfte [...], unabhängig davon, ob diese Kräfte bewußt den Sprachgebrauch zu beeinflussen versuchen. (Stötzel/Wengeler 1995, p. 1)

[the intentions and interpretations of significant forces in society[...], no matter whether they have the intention to change language use.] 
The analysed newspaper articles are taken exclusively from the newspaper corpora held at the IDS Mannheim. The following newspapers were selected: The weekly Die Zeit and the daily papers Berliner Zeitung $(B Z)$ and die tageszeitung (taz). As some of the IDS corpora do not cover all issues for the last few years, the sources are as follows:

Period 1 - Die Zeit; die tageszeitung;

Period 2 - Die Zeit; die tageszeitung; Berliner Zeitung;

Period 3 - Die Zeit; die tageszeitung; Berliner Zeitung.

Features of the Lexeme Euro with Regard to Grammar and Word Formation

\section{Grammar}

Euro as the representation of the lexicalised name for the currency unit of the European Economic and Monetary Union may be explained as the unisegmental short form of the initial segment of European Currency Unit.

Like many other currency names, Euro is a masculine noun in German, thus der Euro just like der Heller, Taler, Dollar, Schilling, Pfennig, Franken, Gulden, Rubel; but: die Mark, die Krone, die Drachme; das Pfund (cf. Duden-Grammatik 1995, p. 198), although there was initially some uncertainty about the gender of the name: 'Denn, soweit ersichtlich, hat Euro kein Geschlecht. Heißt es der Euro, die Euro oder das Euro?' ['For as far as it is possible to tell, Euro has no gender. Is it der Euro, die Euro or das Euro?'] (Die Zeit, 23 February 1996). The sub-unit Cent already displayed the male gender.

Even today, several years after the formation of this neolexeme, the use of inflected forms is still somewhat ambiguous. The uncertainty reflected in the representation of the lexeme Euro in recent dictionaries is a rather common feature with measurement and currency units. The table below shows a comparison of seven language dictionaries with regard to their forms of the singular and plural genitive forms. 
Table 1 Euro - Genitive Forms

Dictionary

1 Duden - Rechtschreibung (1996)

2 Duden - Deutsches Universalwörterbuch (1996)

3 Langenscheidt - Internet (1999)

4 Heyne - Wörterbuch (1997)

5 Bertelsmann - Rechtschreibung (1999)

6 Bertelsmann - Fremdwörterlexikon (1999)

7 Duden - Das große Wörterbuch (1999)
Genitive
Singular

$-[\mathrm{s}]$

$-[s]$

$-1-s$

- / -s

$-s$

$-S$

-s $\quad-s$

$-s \quad-s ;$ if specifying a certain amount: -

$-[\mathrm{s}] \quad-\mathrm{s}<$ but: 10 Euro $>$

We may observe four clearly distinct patterns between dictionaries 1, 2 and 3 (either no ending or the ending $-s$ is possible with both forms), dictionaries 4 and 5 (with both forms, only the ending $-s$ is possible), dictionary 6 (similar to 4 and 5 except for the plural restriction 'no ending if specifying a certain amount') and dictionary 7 (genitive singular same as in 1,2 and 3, plural the same as in 6). The rules given in dictionaries $1,2,3$ and 7 are confirmed by the corpus evidence, i.e. the appearance of variants either having no ending or ending with $-s$.

\section{Word Formation}

Along with the establishment of the neolexeme Euro around 1995, we can observe a novel aspect in word formations with the element 'euro'.

Until then, there had only been numerous - almost exclusively nominal-compounds with 'euro' acting as prefix or prefixoid element (the distinction is somewhat ambiguous in the current literature), summarised by researchers like Born with regard to similar words in other European languages.

According to Born, '[die] Einschätzung von euro- als Präfixoid [trägt] dem internationalistischen Charakter dieses Wortbildungselementes eher Rechnung als die Deutung als ein abgekürztes Substantivkompositionselement ['to regard euro- as prefixoid takes into account the 
internationalistic character of this morpheme better than its interpretation as an abbreviated compound noun element'] (1995, p. 350), as expressed for instance in Duden-Grammatik:

Um Zusammensetzungen handelt es sich z.B. bei Bioladen, Biorhythmus, Euromarkt, bei denen die attributiven Adjektive (biologisch, europäisch) gekürzt in die Wortbildung eingehen, ohne da $\beta$ die Kurzform als selbständige Einheiten existieren. (1995, p. 411)

[There are compounds such as Bioladen, Biorhythmus, Euromarkt etc., where the abbreviated attributive adjectives (biologisch, europäisch) enter the word formation process without being free morphemes themselves.]

The morpheme 'euro' can have different meanings such as 'European', 'concerning Europe', 'made in Europe' etc. Among the areas listed by Born as containing these compounds are EU and EU-related institutions (e.g. Eurokratie, Europarlament, Eurorichtlinien, Euronormen), the financial sector (e.g. Eurowährung, Eurobank, Euroanleihen), but also research, technology, communication, sport and transport. Although we need not and cannot go into detail here, we should keep this background in mind when examining word formations with the neolexeme Euro. Euro as currency denominator is a noun and may form compounds with other lexemes - mostly nouns, - which it frequently does. It is not always clear from the semantic construction, whether it is the prefix(oid) euro- or the noun Euro that makes up the first part. Even the context does not always give clues. Here, a clearly defined graphematic convention would be helpful, for instance with prefix(oid) constructions written as one word (without a hyphen), compounds on the other hand requiring a hyphen, i.e. Eurobürokratie, Eurokartell, Eurotunnel etc., but Euro-Kriterien, Euro-Logo, Euro-Münze, Euro-Start, Euro-Umstellung and so on. However, corpus evidence is showing a more confused situation, as Born states just for the spelling of the prefix(oid) compounds (1995, p. 356): 'In der Realität läßt sich ein ziemlich unmotiviertes Durcheinander beobachten. Die Faustregel, Ad-hoc-Bildungen mit Bindestrich, Lexikalisierung ohne läßt sich jedenfalls bezüglich euro- nicht bestätigen'. ['In reality, we find a state of confusion. The rule of thumb to hyphenate ad-hoc-formations and write lexicalised units as one word obviously does not hold true for euro-'.]

The situation becomes even more complicated when looking at compounds with the currency denominator Euro. For instance, does 
Euroskepsis/Euro-Skepsis mean 'scepticism towards Europe' or 'scepticism towards the currency unit Euro'?

\section{Analyses and Interpretations}

In this section we will present the results gained from the examination of language use based on texts from the three different periods. In the following, all stages are assigned to separate sections of a similar structure. Firstly, we will examine the usage of the lexeme Euro in the relevant period, with special regard to collocations. We define 'collocation' in a wider sense as combinations between Euro and other lexemes, realised within the corpus as syntactic entities showing a distinct usage of Euro. We will then summarise and interpret those collocations according to their different semantics and content.

Under the sub-title 'word formation' we will then have a look at word formations with Euro. Here too, we will summarise and interpret the occurrences after grouping them.

For reasons of space, only very few of the discussed collocations and compounds could be shown in their larger context and with full reference to the source.

Period 1: Decision to assign the name Euro to the new common currency of the European Union (November/December 1995, January/February 1996)

Here, the public discussion is mainly concerned with the decision made by the Heads of State and Government of the European Union during the Madrid summit meeting held 15/16 December - as outlined before - to follow the proposal of the then German Minister of Finances Theo Waigel to assign the name Euro to the new common currency. Prior to this official decision, there had been discussions on different levels about a variety of alternatives, still reflected in the texts of this period, as illustrated in the sample given below: Here, the taz quoted the results of a survey launched by the British newspaper The Guardian in conjunction with eleven other European daily newspapers, the taz among them. The survey, carried out centrally by The Guardian, led to the following results with regard to the question of how to name the new currency:

Die Mehrheit, $36 \%$ aller europaweit Befragten, wolle es Ecu nennen, an zweiter Stelle rangiert die Euro-Mark, Euro-Pfund, Euro-Franc usw. 
Finanzminister Theo Waigels Vorschlag, die neue Währung Euro zu nennen, erreichte einen respektablen dritten, unter taz-LeserInnen sogar den zweiten Platz. Dukat, Florin und Franken konnten nur Achtungserfolge erzielen. Weitere Vorschläge waren Euro-Dollar, Taler (in Anspielung auf die Valuta Entenhausens), Pfifferling, Stein, WaiGeli oder Wolpertinger. (taz, 13 December 1995, p. 8)

[The majority, 36 percent of those questioned in the whole of Europe, favoured Ecu, followed by Euro-Mark, Euro-Pound, Euro-Franc etc. The proposal of the Minister of Finance, Theo Waigel, to name the new currency Euro, came a respectable third, among taz readers it even ranked second. Ducat, Florin and Franc only gained polite acclaims. Among the other suggestions were Euro-Dollar, Taler (an allusion to the German name for the currency used in Ducksburg), Pfifferling ('chanterelle', a reference to the German idiomatic expression keinen Pfifferling wert, roughly to be translated as 'not worth a bean' in English), Stein ('stone'), WaiGeli or Wolpertinger'. (name of a mythological Bavarian creature)]

After the official decision was taken in favour of Euro, there followed a short period where some linguistic aspects - such as its pronunciation or gender in the different languages of the participating countries - and questions concerning the introduction of the new currency were the subject of discussion. Here, we have to distinguish between those collocations that refer to the introduction of the Euro in a neutral way and others expressing the collocation partners' approval or disapproval or a positive or negative attitude towards the Euro. Thus, the collocations prevailing in the texts of this period can be classified according to four collocation areas, to which all frequently recurring and other typical collocations have been assigned:

Examples for collocations referring to the term Euro for the common European currency:

die Bezeichnung, die Währungsbezeichnung, der Name Euro

die neue Währung Euro nennen, taufen

die neue Währung, das Kind soll / wird Euro heißen

Euro sei dein Name (see Example 1 below)

an den Euro die alte Währung anhängen

Euro ist polysem, hat kein Geschlecht

ein mit 'Euro' bedruckter Geldschein

Example 1:

Der portugiesische Regierungschef Antonio Guterres fand auf dem EU-Gipfel vor ein paar Tagen die richtigen, weil biblischen Worte dafür: 'Euro sei dein Name, und auf diesem Euro werden wir unser Europa errichten'. (taz, 21 December 1995, p. 10) 
[At the EU summit a few days ago, the Head of the Portuguese Government, Antonio Guterres, found the right, because biblical, words for this: 'Euro be thy name and upon this Euro we shall build our Europe'.]

Examples of collocations referring to the introduction of the Euro:

Einführung des Euro, der EU-Währung Euro

Start des Euro

Startschuß für den Euro

Endspurt des Euro

der Euro kommt

der Euro wird Wirklichkeit, wird geschaffen, erblickt das Licht der Welt

den Euro bekommen, kriegen, haben

die Geburtsstunde für den Euro schlägt

für den Euro werben, die Werbetrommel rühren

Übergang zum Euro

Umstellung der Mark auf den Euro

die D-Mark wird zum Euro, soll dem Euro Platz machen

in Euro umrechnen

mit (dem) Euro bezahlen

Rechnungen künftig in Euro schreiben

Examples of collocations expressing the collocation partners' agreement or disagreement with the Euro:

Agreement:

den Euro wollen, liebenlernen, ernst nehmen

an den Euro glauben

Disagreement:

den Euro sabotieren, bereits beerdigt haben

Angst vor dem Euro

ungeliebter Euro

emotionale Blockade gegen den Euro

auf Distanz zum Euro gehen

der Euro ist gescheitert

Examples of collocations expressing the collocation partners' positive or negative attitude towards the Euro:

positive: der Euro ist eine gute Sache.

negative: wenig stabiler (see Example 2), weicher, labberiger Euro.

It is a characteristic feature of the texts of Period 1, that the main focus is on the procedure for finding a name for the new European currency and 
certain aspects of its introduction, while in this early period (1995/96) with the real issues concerning the transition to the Euro still rather far ahead - pro and con-statements are comparatively rare. But even at this early point it was feared that the solid, stable Deutschmark would be changed into a weak, unstable Euro:

Example 2:

Gerade in deutschen Köpfen hat sich die Befürchtung festgesetzt, der Euro werde nie so stabil sein wie die Mark. (Die Zeit, 29 December 1995)

[Especially in the heads of the Germans there is a fear that the Euro will never be as strong as the Deutschmark].

\section{Word Formation}

The texts of Period 1 show a range of - mainly nominal - compounds with Euro as qualifying element. However, in some cases we cannot always exclude the possibility of a prefix(oid) formation with euro-: For instance, does Eurowährung / Euro-Währung stand for 'the currency Euro' or simply for 'European currency'? The often inhomogeneous spelling - with or without hyphenation - of one and the same formation type could be partly based on the novelty character and instability of the formation. Generally, hyphenated spellings dominate. It is obvious that the ambiguity of those compounds - including graphematic variance - is sometimes used to play with the language. The compounds with Euro as qualifying element can be roughly classified by the meaning of their base words.

Examples of compounds referring to different aspects of the introduction of the Euro:

Euro-Einführung, Euro-Projekt, Euro-Idee

Euro-Zeitplan, Euro-Ära, Euro-Tag

Euro-Club, Euro-Bürger

Euro-Umfrage

Examples of compounds referring to the monetary aspects of the currency Euro. The graphematic variants mentioned above are mainly found in this group:

Eurowährung/Euro-Währung, Eurogeld/Euro-Geld, Euro-Geldscheine, Euro-Geldmünzen und -Scheine, Euromünzen und -Scheine, Euro-Knete, Euromark/Euro-Mark, Europfennig/Euro-Pfennig, Euro-Franc, EuroLira, Euro-Pfund, Eurocent 
Examples of compounds expressing agreement or disagreement towards the Euro:

Agreement: $\quad$ Euro-Befürworter, Euro-Fans

Disagreement: Euro-Skepsis, euroskeptisch

Euro-Pessimisten, Euro-Skeptiker, Euro-Muffel (see Example 3)

Most occurrences with compounds expressing disagreement refer to the British, e.g.

Example 3:

die als Euro-Muffel verschrienen Briten (Die Zeit, 19 January 1996)

[The British as notorious Euro-grousers]

Period 2: Debate on the fulfilment of the convergence criteria and on the eligibility of the participating countries for membership in the EMU (November/December 1997, January/February 1998)

Similar to Period 1, the part of the survey defined as Period 2 also falls into the second stage of the introduction of the EMU. It covers four months representing a significant cross-section of the discussion on central aspects of creating the EMU. To sum up: This period is marked by the struggle for meeting the convergence criteria as fixed in the Maastricht Treaty of 1992 and ratified by the European Council in Amsterdam in the middle of 1997 under an 'Agreement for Stability and Growth', where the statistical data of 1997 should determine the eligibility of the candidates for participation in the EMU starting in 1999, this decision having been scheduled for the first half of 1998. Obviously, collocations and compounds referring to this background, i.e. introduction of the Euro, criteria for participation in the EMU, attitudes towards the Euro and its assessment are the main issues of this part of our survey.

The name for the new currency itself, Euro, is no longer considered an important issue. Compared to Period 1 there is a wider discussion on possible effects of the Euro, i.e. on future aspects. We do not only detect a different emphasis with regard to content, but also a difference in quantity between the two periods. For instance, the number of occurrences of Euro within a comparable time span of four months has more than doubled (Die Zeit, taz). The higher absolute number of occurrences compared to Period 1 
is the result of adding the Berliner Zeitung ( $B Z$ ) to the survey. The number of types within the compound words (compounds with Euro -) has even multiplied, without doubt due to the increased complexity of the issues dealt with in Period 2. Inevitably, this has led to an increase of tokens within the compounds.

Although below we will list all relevant collocation areas, due to the large number of occurrences we must limit - even more restrictively than in Period 1 - the number of examples to very distinct ones. Still, in accordance with the subject of this volume, those collocation areas expressing attitudes and assessments will be dealt with in greater detail. Let us start with the small area of collocations consisting of a generic concept noun (with a definite article) immediately followed by the currency denominator Euro. The concept noun then acts as core element of the constituent (or attribute), the proper name is to be defined as juxtaposition (close apposition) (Duden-Grammatik 1995, p. 648), for example:

die Gemeinschaftswährung Euro, die Einheitswährung Euro

die (gemeinsame) europäische Währung / Einheitswährung Euro

die künftige gemeinsame Währung Euro

die Euro-Währung Euro

das Gemeinschaftsgeld Euro

The largest area in Period 2 contains collocations referring to the introduction of the Euro, for example:

Vorbereitung auf den Euro, Weg zum Euro

Einführung, Schaffung, Start des Euro

Übergang zum Euro, Umstellung auf den Euro

Kurs des Euro

der Euro kommt, rollt

den Euro einführen

der Euro ist beschlossen, wird Realität, wird verbindliches Zahlungsmittel sich auf den Euro vorbereiten, einrichten

auf (den) Euro umstellen

mit / in Euro bezahlen

Rechnungen, Schecks in Euro ausstellen

Preise in Euro auszeichnen, Waren in Euro auspreisen

Mark-Bargeldbestände in Euro umtauschen

Steuererklärungen in Euro akzeptieren, zulassen

den Aktienhandel in Euro abwickeln 
Some collocations - more or less as a thematic sub-group of this area refer directly to a postponement or non-establishment of the Euro, for instance:

Verschiebung des Euro

der Euro kommt zu früh (see Example 4), muss / kann verschoben werden den Euro noch aufhalten, vorläufig stoppen

\section{Example 4:}

Der Euro kommt zu früh, meinen 155 deutsche Professoren und fordern, die Währungsunion zu verschieben. (Die Zeit, 12 February 1998, p. 20)

[The Euro is too early, such is the opinion of 155 German professors who demand a postponement of the currency union.]

The background for collocations of this kind is the above-mentioned petition by 155 German professors to postpone the currency union and the complaint about infringements of the constitution by four prominent opponents to the Euro, both having taken place in Period 2. However, neither this petition nor the complaint to the Federal Constitutional Court could hinder the scheduled introduction of the Euro on 1 January 1999.

Examples of collocations referring to meeting the so-called convergence criteria as prerequisites for membership in the EMU:

Maastricht-Kriterien, Stabilitätspakt, Stabilitätskriterien,

Konvergenzprogramm für den Euro

Qualifikation, Aufnahmeprüfung, Reifezeugnis für den Euro

Teilnahme, Teilnehmer am Euro

am Euro teilnehmen, sich am Euro beteiligen

beim Euro von Anfang an / mit dabei sein, beim Euro mitmachen

fit, reif sein / werden für den Euro, $X$ fit machen für den Euro

sich für den Euro qualifizieren, für den Euro sparen

$X$ (nicht) vom Euro ausschließen

dem Euro beitreten, angehören

den Euro schaffen (= 'to manage, to accomplish the Euro')

Examples of collocations referring to possible effects of the introduction of the Euro:

Vorteile, Chancen, Gefahren, Risiken, Folgen, Auswirkungen des Euro der Euro eröffnet beachtliche Chancen der Euro wird Europa radikal verändern der Euro schafft (keine) neue(n) Stellen / Arbeitsplätze 
der Euro wird den Arbeitnehmern / Verbrauchern eher schaden

der Euro heizt die Immobiliennachfrage an

der Euro verbindet, trennt, lockt

Spaltung durch den Euro

Urlaub mit dem Euro

mit dem Euro rechnen müssen

vom Euro profitieren

Herr über den Euro (see Example 5)

Example 5:

Wer wird Herr über den Euro? Die Mitgliedsländer der EU ringen um die Spitzenpositionen bei der Europäischen Zentralbank (Die Zeit, 13 February 1998)

[Who will be master of the Euro? The EU member states struggle for the leading positions in the European Central Bank]

The occurrences often refer to expected effects on the economy in general, on banking, on the labour market and on tourism. Whereas sceptical attitudes prevail with regard to the labour market, the effect on the other areas is seen rather optimistically.

The following collocation areas with collocations expressing attitudes towards and assessments of the Euro have both been already detected in Period 1. However, with the political, juridical and verbal debates concerning the establishment of the Euro reaching their climax in Period 2, compared to Period 1 collocations of the above type claim a larger part with regard to the overall number of collocations with Euro. On the same level, there is a considerable increase in the variety of the collocation partners.

Examples of collocations expressing the collocation partners' agreement or disagreement towards the Euro:

Agreement:

Befürworter des Euro, pro Euro

den Euro befürworten, wollen, brauchen, zum Erfolg führen

auf den Euro setzen

Entscheidung, Zustimmung, Mehrheit, Argumente, Kampf, Bündnis für den Euro

für den Euro sprechen, argumentieren

sich für den Euro aussprechen, stark machen

Vertrauen in den Euro haben

fest, voll und ganz hinter dem Euro stehen

positiv über den Euro denken 
vom Euro überzeugt sein

Bekenntnis, Ja zum Euro

sich zum Euro bekennen, fest zum Euro stehen

Disagreement:

Gegner, kein Freund des Euro

Ablehnung des Euro

der Euro ist ungeliebt, hat viele Gegner, wird scheitern, ist 'out'

den Euro fürchten, scheuen, nicht wollen, geißeln, skeptisch beurteilen (see Example 6), noch kippen, in Frage stellen

dem Euro mit Skepsis entgegensehen

sich dem Euro widersetzen

Absage an den Euro, Kritik am Euro

Widerstand, Abneigung, Wahlkampf, Klage, Verfassungsbeschwerde, Votum, Volksbegehren, Volksbefragung, Demonstration, Opposition gegen den Euro Kläger, Agitator gegen den Euro gegen den Euro sein, klagen, agitieren, mobilisieren, Stellung beziehen sich gegen den Euro engagieren

Zweifel gegenüber dem Euro dem Euro gegenüber negativ eingestellt sein über den Euro streiten, (Dauer)streit um den Euro vom Euro nicht überzeugt sein, wenig vom Euro halten Ängste, Warnung vor dem Euro sich vorm Euro fürchten

Rettung der D-Mark vor dem Euro wider den Euro

Nein, kritische Haltung zum Euro

Example 6:

Die Mehrheit der Deutschen beurteilt den Euro weiterhin skeptisch. $(B Z, 30$ December 1997)

[The majority of Germans is still sceptical towards the Euro.]

Even this limited selection clearly shows that the collocations expressing disagreement are far more frequent and varied in expression than those expressing agreement, one reason being the influence of the above-mentioned petitions and complaints, not to mention decisions and referenda which have massively affected the press texts throughout the whole period.

Examples of collocations expressing the collocation partners' positive or negative attitude towards the Euro; 
positive:

harter, stabiler, starker, gesunder Euro

erfolgreicher, konkurrenzfähiger Euro

Härte, Stabilität des Euro

Erfolg, Vorteile des Euro

negative:

weicher, schwacher Euro (see Example 7)

der Euro wird nicht so stabil wie die D-Mark sein

der Euro wird weniger hart als die D-Mark sein

der Euro ist risikoreich, riskant, hochinflatorisch, politisch verhängnisvoll

der Euro hält nicht, was man sich von ihm verspricht

Instablität, Unflexibilität, Werteverlust des Euro

\section{Example 7:}

In der jüngsten Entwicklung der Mark sehen die Professoren schon eine Bestätigung ihrer These vom kommenden schwachen Euro. (taz 10 February 1998, p. 2)

[The professors see their prophecy of a weak Euro confirmed by the recent development of the Deutschmark.]

\section{Word Formation}

In Period 2 not only the collocations with Euro, but also the types and tokens of word formations with Euro have clearly increased compared to Period 1 . The variety of the aspects discussed above has obviously led to a greater demand for nominal compounds with Euro as the modifier; with the occasional occurrence also of adjectival compounds. Constructions with Euro acting as base word are extremely rare.

The problem of graphematic variants with or without hyphen, already discussed in the word-formation section of Period 1 above, also exists in Period 2; here too, the hyphenated spellings dominate.

The compounds with Euro as qualifying element can be roughly classified by the meaning of their base words. In addition to the three groups known from Period 1, where the compounds refer to monetary issues and aspects of procedure and attitude, we may classify a new group of compounds which - in accordance with a corresponding collocation area - refer to aspects of meeting the so-called convergence criteria as a prerequisite for membership in the EMU.

Examples of compounds referring to the different aspects of establishing the Euro: 
Euro-Debatte, Eurodiskussion, Euro-Referendum, Euro-Abstimmung Euro-Entscheidung, Euro-Beschlu $\beta$

Euro-Einführung, Euro-Start, Euro-Umstellung, Euro-Umtausch, EuroVerwendung, Euro-Fragen, Euro-Details, Euro-Regularien

Euroeinführungsgesetz / Euro-Einführungsgesetz

Euroverschiebung / Euro-Verschiebung, Euro-Kalender, Euro-Zug (see Example 8)

Euro-Zeitalter, Euro-Ära, Euro-Jahr (= 1998), Euro-Phase

Euro-Beauftrager, Euro-Fachmann, Euro-Stäbe, Euro-Kompetenz

Euro-Bürgertelefon, Euro-Informationsforum, Euro-Hotline

Example 8:

'Der Euro-Zug rollt' - davon sind die Analysten spätestens seit Freitag überzeugt. (BZ, 28 February 1998)

['The Euro train is on its way' - such is the conviction of the analysts at least since Friday.]

Examples of compounds referring to the monetary aspects of the currency Euro:

Euro-Währung, Euro-Bargeld, Euromünzen / Euro-Münzen, Euro-Banknoten, Euro-Scheine

Euro-Aktien, Euro-Kredite, Euro-Pfandbrief, Euro-Wertpapiere, Euro-Steuer, Euro-Zins, Euromieten, Euro-Gehalt, Euro-Konto

Euro-Bank, Euro-Zentralbank, Eurobanker, Eurotower / Euro-Tower Euro-gefördert, Euro-kompatibel

A remarkable difference to Period 1 is the fact that the coming up of practical issues concerning the transition to the Euro led to a majority of those base words referring to various aspects of monetary policy and the financial market.

The formation Eurotower / Euro-Tower (see Example 9), describing the premises of the European Central Bank (ECB) in Frankfurt/M., is not self-explanatory:

Example 9:

Noch ist die Bezeichnung Eurotower für das 150 Meter hohe Domizil des EWI wenig populär. (Die Zeit, 26 February 1998)

[The name 'Eurotower' for the domicile of the ECI, which is 150 metres high, is still not very popular.] 
Examples of compounds referring to meeting the so-called convergence criteria as a prerequisite for membership in the EMU:

Euro-Kriterien, Euro-Teilnahme-Kriterien, Euro-Kennzahlen, Euro-Marke, Euro-Gutachten

Eurotauglichkeit / Euro-Tauglichkeit, eurotauglich / Euro-tauglich, EuroFähigkeit, Euro-Reife, euroreif

Euro-Kandidaten, Euro-Bewerber, Euro-Aspirant, Euro-Qualifikanten Eurobeitritt / Euro-Beitritt, Euro-Teilnahme

Euroteilnehmer / Euro-Teilnehmer, Euro-Teilnehmerländer, EuroTeilnehmerstaaten, Euro-Teilnehmergruppe, Euro-Teilnehmerkreis, EuroStaaten (also: Nicht-Euro-Staaten), Euro-Gruppe, Euro-Start(er)gruppe, Euro-Startteilnehmer, Euroländer / Euro-Länder (see Example 10), EuroMitglieder, Euroclub / Euro-Club, Euro-Club-Mitglieder, Euro-X, Euro-XKlub, Euro-11, Euro-Partner, Euro-Liga, Euro-Union, Euro-Truppe, EuroKreis

Euro-Gebiet, Euro-Zone, Euro-Raum, Euro-Währungsraum, Euroland / Euro-Land (see Example 11), Euro-Markt, Euro-Binnenmarkt

For reasons of space, we have to restrict our comments to a particularly interesting compound: Euroland / Euro-Land

As early as during the preparation stage for the EMU there was a need for a concise, attractive term for the territory of those members of the European Union taking part in the currency union. Generic, common terms such as die Euro-Staaten or die Euro-Länder seemed unsatisfying. Hence, other terms, such as Euro-Zone were discussed.

However, another word won the race: Euroland. It has been suggested that the economic expert and publicist Claus Noé was the first to use this term (cf. Die Zeit, 29 October 1998, p. 28).

Since then, corpus evidence shows two clearly distinctive interpretations of the compound Euroland / Euro-Land (see also the relevant article in Duden - Das große Wörterbuch 1999):

Euro-Land, das (Genitive Singular: Euro-Land(e)s; Plural: Euro-Länder) meaning 'one of the countries participating in the Economic and Monetary Union' as in:

Example 10:

Die Entscheidung über die Euro-Länder soll Anfang Mai fallen. $(B Z, 2$ January 1998)

[The decision regarding the Euro-Länder is scheduled for the beginning of May.] 
Euroland (mostly without article; no plural) meaning 'all countries participating in the Economic and Monetary Union', as in:

\section{Example 11:}

Beide [Trichet und Duisenberg] stehen im Rennen um den Job des obersten Währungshüters in Euroland. (Die Zeit, 14 January 1997, p. 3)

[Both [Trichet and Duisenberg] are among the front runners for the job of first custodian of the currency in Euroland.]

Unfortunately, this semantic difference is not as clearly distinguished in real language as may be suggested by the above extracts. They are albeit relatively rare - hyphenated spellings for variant 2 , as well as compound spellings for variant 1 . However, the adoption of variant 2 in common language use results in a preference for the compound forms.

Examples of compounds expressing agreement or disagreement towards the Euro;

Agreement:

Euro-Bekenntnis, Euro-Aufruf, Euro-Kampagne

Euro-Erfolg, Euro-Boom, Euro-Euphorie (also as pun using contamination:

Euro-phorie, see Example 12)

Euro-freundlich, euroselig

Euro-Befürworter, Euro-Sympathisanten, Euro-Freund, Euro-Fan

Example 12:

Euro-phorie in Brüssel (Die Zeit, 5 December 1997)

[Euro-phoria in Brussels]

Disagreement:

Eurofeindlichkeit / Euro-Feindlichkeit, Euro-feindlich, Euroskepsis / EuroSkepsis, euroskeptisch / Euro-skeptisch, Euroskeptizismus, Europessimismus, Euro-Protest, Euroangst / Euro-Angst, Euro-Müdigkeit

Euro-Protest, Eurostreik, Euronörgeleien

Euro-Kritik, Euro-Klage, Euro-Streit, Euro-Terror

Euro-Sackgasse, Euro-Krise, Euro-Zwänge, Euro-Unheil

Eurogegener / Euro-Gegner, Euroskeptiker / Euro-Skeptiker (see Example

14), Euro-Kritiker, Euro-Kläger, Euro-Blockierer, Euro-Rebell, Euro-

Dissident

Period 2 shows the first appearance of a new formation type among the compounds expressing approval or disapproval by placing the 
constituents Pro-Euro- or Anti-Euro- respectively in front of base words that themselves are neutral with regard to the Euro, such as:

Pro-Euro-Kampagne, Pro-Euro-Manifest, Pro-Euro-Stimmung

Anti-Euro-Initiative, Anti-Euro-Klage, Anti-Euro-Erklärung, Anti-Euro-

Diskussion, Anti-Euro-Werbung, Anti-Euro-Kurs, Anti-Euro-Linie, Anti-

Euro-Volksbegehren (see Example 13), Anti-Euro-Partei

Anti-Euro-Kämpfer, Anti-Euro-Kläger

Example 13:

Vom 24. November bis 1. Dezember liegt sein (= Jörg Haiders) Anti-Euro-

Volksbegehren zur Unterschrift aus (taz 24 November 1997, p. 11)

[From 24 November until 1 December his (= Jörg Haider's) petition for a referendum against the Euro is on display for people to sign.]

In period 2, the total number of types and tokens expressing disapproval clearly exceeds those expressing approval. Compared to period 1 , there is a significant difference with regard to content. Whereas in period 1 most occurrences deal with the topic of disagreement as a matter of principle (especially from the British side), in period 2 the texts reflect the opposition and scepticism within the potential participants of the EMU, for instance:

\section{Example 14:}

Frankreichs Euro-Skeptiker machen erneut gegen den EU-Vertrag von Amsterdam mobil. (taz, 3 January 1998, p. 5)

[Again, the French Euro-Sceptics mobilise against the EU Treaty of Amsterdam.]

Our corpus evidence shows only three occurrences of compounds with Euro acting as base word in period 2: 'Silber-Euro', 'Probe-Euro' und 'Peterseuro' (see Example 15), two of them expressing their singular and novel character through quotation marks.

Example 15:

Die Umwandlung des Peterspfennigs in einen 'Peterseuro' (Die Zeit, 26

December 1997, p. 16)

[The conversion of St. Peter's Penny into 'St. Peter's Euro']

Period 3: Introduction of the Euro as 'ledger currency' on 1 January 1999 (November/December 1998, January/February 1999) 
On 1 January 1999 the third and last stage of the EMU began. On this day, the eleven participants of the European Currency Union centralised their financial policy under the European System of Central Banks (ESCB) and introduced the Euro as common currency: until the end of 2001 as a so-called 'ledger currency' parallel to their local currencies, from 1 January 2002 as legal tender, with local banknotes and coins being abolished from 1 March 2002. The survey section defined as Period 3 ranges from two months ahead of 1 January 1999 to two months after that date, so that the reflection of the transition process - the final preparation for the transition, the deadline, the first weeks with the new 'ledger currency' Euro - in the chosen press media will be fully covered by the survey. The majority of the collocations and compounds in Period 3 deal with aspects of the introduction and in particular with the monetary aspects of the Euro currency, now for the first time appearing in reality. Aspects of attitude and assessment are also frequent subjects of discussion in this period. Collocations following the pattern 'generic concept noun+Euro' or referring to aspects of participation in the EMU or possible consequences show only small areas.

The large number of collocations and compounds made it again necessary to choose only a very limited set of distinctive examples for illustration.

To ensure a maximum comparability of results, the arrangement of collocation is the same as in Period 2. The extensive collocation area dealing with monetary aspects, appearing here for the first time, follows the one dealing with aspects of the introduction of the Euro, as both belong to the same context.

Let us again begin with the small area of collocations consisting of a generic concept noun (with a definite article) immediately followed by the currency denominator Euro. Examples:

die Gemeinschaftswährung Euro, die Einheitswährung Euro

die europäische Währung/Einheitswährung Euro

die einheitliche/gemeinsame/neue Währung Euro

Next follow the by far largest collocation areas dealing with aspects of the introduction of the Euro. Due to the large number of aspects, we have decided - different to Period 2 - to structure the overall area by distinguishing between general collocations and those referring to concrete monetary and banking aspects in two different sub-groups. There is no need to comment on these collocations as they are self-explanatory. 
Examples of collocations referring to the introduction of the Euro:

Einführung, Schaffung, Start, Ankunft, Beginn, Geburt(sstunde), Jahrzehnt, Zeitalter, Europa des Euro

Vorläufer des Euro (= Ecu)

Stadt (see Example 16), Hauptstadt, Kapitale des Euro (= Frankfurt/Main)

der erste Tag, das erste Jahr des Euro

der Euro kommt, rollt, startet, gilt, tritt in Kraft

der Euro steht vor der Tür, ist auf den Weg gebracht, hat seinen Einzug gehalten

der Euro existiert, ist da, wird konkret, ist Realität

der Euro lebt, ist geboren, hat das Tageslicht erblickt, wurde zum Leben erweckt

der kommende, nahende, frische, neugeborene Euro

die ersten Euros

dem Euro gelassen entgegensehen

den Euro einführen, begrüßen

sich an den Euro gewöhnen

sich auf den Euro einstellen, vorbereiten

Vorbereitung, Aussicht, Warten auf den Euro

für den Euro fit, gerüstet sein

der Umgang mit dem Euro

Volksabstimmung über den Euro

Aufwand, Diskussionen rund um den Euro

Übergang, Vorbereitungen zum Euro

Fragen, Antworten, Infos zum Euro

Example 16:

'Stadt des Euro', wie sich Frankfurt nennt (Die Zeit, 28 January 1999)

['City of the Euro', as Frankfurt calls itself]

Examples of collocations referring to monetary and banking aspects of the Euro:

2 Euro, ein halber Euro, mehrere Milliarden Euro

der Euro fällt, wertet ab, gibt nach

den Euro testen, verwenden

Kurs, Wert, Preis des Euro

Anschub, Aufwertung, Überbewertung, Wertzuwachs, Kursrückgang des Euro Produktion, Erstausgabe des Euro

Herr des Euro (= Wim Duisenberg), Verwalterin des Euro (= European

Central Bank) 
Wettbewerbsvorteile des Euro

sich am Euro orientieren

auf Euro umschreiben, umstellen, umrechnen

auf Euro lauten, laufen

Umstellung, Umrechnung auf Euro

Zinssatz, Quotierungen, Zielzonen für den Euro

in Euro (be)zahlen, abrechnen

Konten in Euro führen

Rechnungen in Euro ausstellen, transferieren

Schecks in Euro ausfüllen, akzeptieren

Beträge in Euro überweisen, umrechnen, ausweisen, angeben

Einlagen, Kurse, Preise, Forderungen in Euro

Auszeichnung, Bezahlung, Handel, Umrechnung in Euro

Noten, Scheine, Münzen in Euro

mit Euro zahlen

Handel, Umsatz mit Euro

Nachfrage nach Euro

Kontrolle, Kommando über den Euro

Umtauschkurs, Wechselkurs zum Euro

Examples of collocations referring to aspects of membership in the EMU:

Qualifizierung für den Euro

(Nicht)Teilnahme am Euro, Beitritt zum Euro (see Example 17)

Teilnehmerländer des Euro / am Euro

Außenvertretung des Euro

noch nicht am Euro teilnehmen

beim Euro mitmachen

dem Euro vorerst fernbleiben

Example 17:

Blair bereitet britischen Beitritt zum Euro vor [Überschrift] (Die Zeit, 28 January 1999)

[Blair prepares for British participation in the Euro [Headline]] (BZ, 24 February 1999)

It is not surprising that with the participants of the EMU already fixed and the actual transition to the Euro being the centre of interest, the above collocation type plays a minor role compared to Period 2.

The possible consequences of the introduction of the Euro are still a matter of debate in Period 3, however, the prognostical aspects are clearly dominated by those dealing with the concrete transition to the Euro.

Examples of collocations referring to possible consequences of the introduction of the Euro: 
Folgen, Folgewirkungen, Wirkungen, Auswirkungen des Euro

Chancen, Risiken des Euro

die (internationale) Rolle, die Zukunft des Euro

der Euro als Motor der Integration

den Euro als Chance begreifen

der Euro bringt Nutzen, Vorteile

der Euro begünstigt Investitionen, treibt Investitionen an

der Euro macht uns stark (see Example 18)

der Euro schafft Unsicherheit

Example 18:

Eine breite Werbekampagne mit dem Slogan 'Der Euro macht uns stark' (taz, 15 January 1999, p. 4)

[A broad publicity campaign with the slogan 'The Euro will make us strong']

A remarkable fact is the lesser frequency of negative articulations compared to positive ones - a clear difference to Period 2. This is obviously a result of the advancing and irrevocable introduction of the Euro in the member states of the EMU: there is not much sense anymore in evoking pessimistic prognoses as a warning against the Euro.

Both the following collocation areas expressing the same aspects with regard to attitudes and assessments already mentioned in Period 1 and 2, draw a strikingly different picture compared to earlier periods, in particular to Period 2. Apart from a decreasing frequency of such collocations in general, there is a significant majority of collocations expressing agreement or a positive attitude, one plausible reason being that with the Euro now a reality, the warning and equivocal voices obviously step back behind those who bear in mind the inevitable facts and try to seek the positive aspects of the Euro.

Examples of collocations expressing the collocation partners' agreement or disagreement towards the Euro;

Agreement:

Beliebtheit, Popularität, Begrüßung, Glaubwürdigkeit des Euro Anhänger, Freunde. Befürworter des Euro

den Euro befürworten, loben, feiern, akzeptieren, unterstützen, stärken, wollen

der Euro ist in, erzeugt Hoffnungen

große Erwartungen an den Euro

positive Reaktionen auf den Euro 
optimistisch auf den Euro blicken, sich auf den Euro freuen

für den Euro sein

Sympathie, Begeisterung, Hauptargumente, Kampagne für den Euro

sein Heil im Euro suchen (see Example 19)

Zustimmung zum Euro

Example 19:

Diesmal könnten die roten Zahlen Blair dazu verleiten, doch noch sein Heil im Euro zu suchen. (taz, 5 November 1998, p. 2)

[Being in the red, Blair could be tempted to seek his salvation in the Euro after all.]

Disagreement:

unpopulärer Euro

den Euro ablehnen, nicht wollen, nicht brauchen

dem Euro nicht über den Weg trauen

der Euro erzeugt Ängste, scheitert

Vertrauensverlust für den Euro

gegen den Euro sein, stimmen

Mißtrauen, Vertrauensschwund in den Euro

Angst, Panikmache vor dem Euro

Examples of collocations expressing the collocation partners' positive or negative attitude towards the Euro;

positive:

harter, stabiler, starker, fester, steigender Euro

Stabilität, Stärke des Euro

Erfolg, Vorteil, Vorzüge, Glanz des Euro

vom Euro profitieren

negative:

weicher, schwacher, geschwächter, instabiler, leichter Euro

Schwäche, Probleme, Kehrseite des Euro

den Euro schwächen

\section{Word Formation}

The same four content-defined groups detected for Period 2 also appear in Period 3. However, a certain shift in quantity can be stated for those compounds having a parallel within the collocation areas, i.e. a strong increase in compounds referring to monetary and banking aspects. There is also a rather striking number of compounds referring to aspects of 
membership in the EMU. In particular, there is a large number of those types of compounds representing the EMU member states as a whole. This comes as no surprise given the communicative need for formations illustrating the unifying power of the Euro just at the time when the common European currency finally becomes reality. As in the previous period, nominal formation and hyphenation prevails.

Examples of compounds referring to the different aspects of the establishment of the Euro:

Euro-Debatte, Euro-Informationen, Euro-Fragen, Euro-Vorbereitungen,

Euro-Aspekte, Euro-Projekt, Euro-Experiment, Euro-Erwartungen

Euro-Entscheidung, Euro-Initiative

Euro-Rhetorik, Euro-Vokabular

Euroeinführung / Euro-Einführung, Euro-Test, Eurostart/Euro-Start, Euro-

Debüt,

Euroumstellung/Euro-Umstellung, Euro-Stufenfahrplan, Euro-

Terminkalender, Euro-Übergangszeit, Euro-Einführungsgesetz

Euro-Erstausstattung, Euro-Automat, Euro-Update

Eurobeauftragter / Euro-Beauftragter, Euro-Experte, Euro-Spezialist, Euro-

Projektleiter, Euro-Macher

(erster) Euro-Tag, (erste) Euro-Wochen, Euro-Ära

Euro-Feier(lichkeiten), Euro-Party, Euro-Dinner

Euro-Symbol, Eurozeichen/Euro-Zeichen

Euro-City, Euro-Metropole (= Frankfurt/Main)

Eurotower / Euro-Tower, Euro-Turm

Euro-Briefmarke, Euro-Uhr (see Example 20), Euro-Schlips, Euro-Weste eurotauglich, eurofähig / Euro-fähig, eurokompatibel

Example 20:

Die Euro-Uhr in Frankfurt zeigte den Countdown bis zur Währungsunion. (BZ 2 January 1999)

[The Euro-Clock in Frankfurt displayed the countdown to the currency union.]

Examples of compounds referring to monetary aspects of the currency Euro:

Euro-Währung (also: Nicht-Euro-Währungen), Eurogeld / Euro-Geld, EuroBargeld, Euro-Beträge, Euro-Summen, Euromünzen/Euro-Münzen (also: Zwei-Euro-Münze, Zwei-Euro-Stücke), Euro-Banknoten, Euro-Noten, EuroGeldscheine, Euro-Scheine

Euro-Zahlung(en), Euro-Überweisung, Euro-Buchungen, Euro-Umtausch, Euro-Konto, Euro-Bank, Euro-Zentralbank, Euro-Notenbank, Euro-Zentrale, Euro-Haushalt, Euro-Geldpolitik, Euro-Vermögen, Euro-Werte, Euro- 
Außenwert, Euro-Finanzmarkt, Euro-Geldmarkt, Euro-Aktienmarkt, EuroRentenmarkt, Eurokurs(e) / Euro-Kurs(e) (also: Euro-Dollar-Kurs), EuroWechselkurs, Euro-Umrechnung(skurs), Euro-Niveau, Euro-Aktien, EuroAnleihe(n), Euro-Aktienbarometer, Euro-Aktienindex, Euro-(Stoxx-)Index, Euro-Libor, Euro-Fixing, Euro-Anpassung, Euro-Überbewertung, EuroWertpapiere, Euro-Pfandbrief, Euro-Darlehen, Eurobonds/Euro-Bonds, Euro-Schuldschein, Euro-Tagesgeld, Euro-Börsen, Euro-Zinsen, EuroLeitzinsen, Euro-Tarife, Euro-Transaktionen, Euro-Orders, Euro-Reserve, Euro-Preisauszeichnungen, Euro-Steuererklärungen Eurohüter, Euro-Währungshüter, Eurobanker, Euro-Koordinator, EuroSchuldner

Euro-Taschenrechner, Euro-Taste (see Example 21) Euro-spezifisch

\section{Example 21:}

Für den Ausnahmefall sind die Kassen seit Anfang des Jahres mit einer EuroTaste ausgestattet. Ein Knopfdruck genügt und der Mark-Betrag wird umgerechnet. (BZ, 5 January 1999)

[For this exceptional case, the cash points have (since the beginning of the year), been equipped with a special Euro-button. One touch of the key and the amount in Deutschmarks will be converted.]

Examples of compounds referring to aspects of membership in the EMU:

Euro-Kriterien, Euro-Anforderungen, Euro-Tauglichkeit, euro-fähig Euro-Beitritt, Euro-Abstinenz, Euro-frei (see Example 22)

Euro-Anwärter, Euro-Aspiranten, Euro-Bürger (also: Nicht-Euro-Bürger)

Euro-Abstinenzler, Euro-Außenseiter, Euro-Outsider, Euro-Nachzügler

Euro-Teilnehmer, Euro-Teilnehmerstaaten, Euro-Teilnehmerländer, Eurostaaten / Euro-Staaten (also: Nicht-Euro-Staaten)

Euroländer / Euro-Länder (also: Nicht-Euro-Länder), Euroland / Euro-Land, Euro-Kernländer, Euro-Mitgliedsländer, Euro-Mitgliedstaaten, EuroNationen, Euro-Regierungen, Euro-Partner(staaten), Eurozone / Euro-Zone, Euroraum / Euro-Raum, Euro-Gebiet, Euro-Währungsgebiet, Euro-Bereich, Euro-Welt, Euro-Europa, Euro-Klub / Euro-Club, Euro-Block, Euro-

Verbund, Euro-Gruppe, Euro-Kartell, Euro-Gilde, Euro-11 / Euro-Elf, Euro11-Gruppe / Euro-Elf-Gruppe, Euro-11-Zone, Euro-11-Partner

Euro-Ausland

Euro-Welthandel, Euro-Stabilitätspakt, Euro-Vertretung, Euro-Gipfel, EuroElf-Rat, Euro-11-Präsidentschaft

euro-weit

Euro-Zeitalter, Euro-Zeit 
Example 22:

Großbritannien noch lange Euro-frei [Überschrift] (taz 4 November 1998, p.

11)

[Great Britain will remain Euro-free for some time to come[Headline]]

Examples of compounds expressing agreement or disagreement towards the Euro:

\section{Agreement:}

Euro-Begeisterung, Euro-Enthusiasmus, Euro-Euphorie (see Example 23; also realised as pun using contamination: Europhorie / Euro-Phorie, europhorisch)

Euro-Manie, Eurowahn

Euro-freundlich, europhil

Eurobefürworter / Euro-Befürworter, Euro-Anhänger, Euro-Anhängerschaft, Euro-Optimisten, Euro-Enthusiasten, Euro-Konvertit (= Blair)

Example 23:

Die vorgesehene Übergangszeit von drei Jahren bis zur Ausgabe des neuen Geldes sei angesichts der Euro-Euphorie 'vielleicht eine zu lange Zeit'. (BZ 11 January 1999)

[The envisaged transition time of three years until the new banknotes and coins are issued could be considered 'perhaps too long' with regard to the prevailing Euroeuphoria.]

Also belonging to the above group regarding their content are the formation europhil, which we consider as a confix compound (for an explanation of this term cf. Fleischer 1995, p. 64) and the derivation Eurotiker, a pun based on Neurotiker which had been used as the counterpart of Euroskeptiker in a 'taz-Euro-quiz' (taz, 30 December 1998).

\section{Examples of disagreement:}

Euro-Verweigerung, Euroskepsis / Euro-Skepsis, Euroskeptizismus, euroskeptisch / Euro-skeptisch, eurofeindlich, eurokritisch, Euro-Angst, Euro-Ängste, Europhobie / Euro-Phobie, Euro-Gegner, Euro-Kritiker, Euroskeptiker / Euro-Skeptiker

Although remarkably less frequent than in Period 2, Period 3 also contains some types of compounds expressing approval or disapproval through the constituents Pro-Euro- or Anti-Euro- respectively: 


\section{Pro-Euro-Entscheidung \\ Anti-Euro-Wahlkampf, Anti-Euro-Tumulte}

First occurring in Period 3 is the small group of compounds expressing a positive or negative attitude towards the Euro through positive or negative features of the base word; a function predominantly - in Periods 1 and 2 even exclusively - covered by collocations.

Examples of compounds expressing a positive or negative attitude towards the Euro;

positive: Euro-Stabilität

negative: Euro-Schwäche

Compounds with Euro as base word are isolated cases also in Period 3. It seems, however, that the formation pattern is no longer regarded as very unusual as none of the three occurrences is put between quotation marks:

EU-Euro does not need any further explanation. Schokoladen-Euros were handed out at the so-called 'changeover weekend' in Frankfurt/Main. Uni-Euro is a term often used in the discussion on the introduction of the European Credit Transfer Scheme (ECTS) at German universities.

\section{Conclusion}

The decision made at the end of 1995 to assign the name Euro to the new European currency led to the coining of a European neologism which in the following years was to act not only as a currency designation, but outside its own scope serve as a theme word and nucleus for aspects of European integration. With the lexeme Euro itself being neutral and impartial, attitudes and assessments towards the Euro can only be expressed by using the relevant collocation partners or constituents. The same applies to all other usage aspects, where the communicative power of this neolexeme is evident in its collocations and constructions. For our analysis of the dynamic use of the lexeme Euro we have chosen three cross-sections illustrating common language use with reference to historic dates, events and developments in the years 1995 to 1995. Each of these sections corresponds to a survey period of four months based on texts taken from the newspapers Die Zeit, die tageszeitung (taz) and Berliner Zeitung (BZ), thus reflecting the common language use of the period in question. The 
results from these analyses, referring to the expressions based on the lexeme Euro have been presented in three sections of a similar internal structure.

Unlike collocations, which may contain nearly all aspects, compounds are subject to various restrictions. For instance, the aspects of the name and the possible effects of the Euro are exclusively represented by collocation areas, not by compounds.

With regard to word formation, compound nouns predominate, most of them hyphenated. Compounds using Euro as base word are rare exceptions, as are derivations of Euro.

Among the eight collocation areas and compound groups that have been structured by their content, the following two appear to be most relevant with regard to communicative powers: those referring to various aspects of the introduction of the Euro and those expressing approval or disapproval of the Euro. Both groups are widely represented in all three periods both with collocations and compound forms.

With the other areas or groups we may observe a sometimes striking clustering in relation to the historic events taking place in the relevant periods. For instance, Euro as currency denominator is only discussed in Period 1, the aspect of meeting the convergence criteria as a prerequisite for membership in the EMU, however, is not yet considered an important issue during that period, but is dominant in Period 2. Due to the nature of the subject, monetary and banking aspects prevail in Period 3, when the transition to the Euro became reality.

The survey period clearly shows two distinctive phenomena with regard to the aspects of attitude and assessment. These aspects can easily be classified by their content: agreement/disagreement; positive vs. negative assessment; possible effects of the Euro.

The first phenomenon is the distinct shift from con to pro through the periods: Whereas periods 1 and 2 show a mainly negative, disapproving or at least reluctant attitude, this changes in the course of periods 2 and 3, displaying an increasing number of occurrences expressing a more positive, approving and optimistic attitude. This change is apparently due to the power of fact, i.e. the actual realisation of the currency union.

Secondly, we may observe that within Period 1 - representing a comparatively early stage of the discussion about the pros and cons of a common currency - occurrences expressing a negative or disapproving attitude tend to be attached to potential 'opt-out'-countries such as Britain, whereas in period 2, which shows a vast increase of those negative 
occurrences, they are more related to arguments within 'Euroland' or individual member states. For instance, in Germany the predominance of occurrences expressing negative attitudes is most certainly due to the professors' petition and the complaint about a violation of the constitution brought to court by four prominent opponents to the Euro.

The present survey has been strongly motivated by the author's belief that the currency designated by the lexeme Euro will rise above itself in playing an important role in the creation of a common European identity. A final quote from the Berliner Zeitung will serve to emphasise this:

Dabei ist die Einfuihrung der Einheitswährung selbst ein erster Schritt zur Schaffung dieses neuen Gefuihls der Zusammengehörigkeit. Der Euro könnte zu einem wichtigen Identifikationssymbol für Europa werden. Denn zum ersten Mal werden alle Europäer gemeinsam etwas besitzen. Allein die sinnliche Erfahrung, in ein anderes Land zu kommen und mit seinem »eigenen « Geld bezahlen zu können, verändert das Gefühl von Fremde und Heimat. Bisher speiste sich europäische Gemeinsamkeit vor allem aus der Idee, zusammen neue Kriege zu verhindern. Jetzt kommt etwas sehr Konkretes hinzu. Identität entsteht auch durch die Alltäglichkeit des Umgangs mit Dingen. Der Euro macht Europa anfaßbar. (Berliner Zeitung 30 December 1998)

[The introduction of a common currency is itself a first step towards a feeling of togetherness. Thus, the Euro could become an important symbol for the identification with Europe, as for the first time, all European citizens share a common possession. Just the emotional perception of entering a foreign country and still being able to pay with one's yown « money will change the feeling of home and abroad. Until now, the idea of a common Europe has mainly been based on the common obligation to prevent a new war. But from now on, there is something else, something concrete. Identity also develops from the things of daily life. The Euro will make Europe tangible.]

\section{References}

Bertelsmann-Fremdwörterlexikon (1999): Wahrig-Fremdwörterlexikon. Neuausgabe, Bertelsmann Lexikon Verlag Gütersloh/München.

Bertelsmann-Rechtschreibung (1999): Die deutsche Rechtschreibung, Bertelsmann Lexikon Verlag Gütersloh, München.

Born, J. (1995), 'Wortbildung im europäischen Kontext - "euro-" auf dem Wege vom Kompositionselement zum Präfix', Muttersprache, vol.105, pp. 347 - 359.

Duden - Der Euro (1998): Der Euro: Das Lexikon zur Währungsunion, Dudenverlag Mannheim, Leipzig, Wien and Zürich.

Duden - Deutsches Universalwörterbuch (1996), 3rd ed., Dudenverlag Mannheim, Leipzig, Wien and Zürich. 
Duden - Grammatik (1995): Grammatik der deutschen Gegenwartssprache, 5th ed., Dudenverlag Mannheim, Leipzig, Wien and Zürich.

Duden - Rechtschreibung (1996): Rechtschreibung der deutschen Sprache, 21 st ed., Dudenverlag Mannheim, Leipzig, Wien and Zürich.

Fleischer, W. (1995), 'Konfixe' in Pohl, Inge, Ehrhardt, Horst (eds), Wort und Wortschatz. Beiträge zur Lexikologie, Niemeyer, Tübingen, pp. 61-68.

Herberg, D. (1999), 'Der Euro - sprachlich betrachtet', Sprachreport, no. 4, pp. 2-7.

Herberg, D. / Steffens, D. and Tellenbach, E. (1997), Schlüsselwörter der Wendezeit: Wörter-Buch zum öffentlichen Sprachgebrauch 1989/90, de Gruyter, Berlin and New York.

Heyne-Wörterbuch (1997): Das neue deutsche Wörterbuch für Schule und Beruf, Heyne, München.

Langenscheidt-Internet (1999): http://www.langenscheidt.aol.de (seen 2 September 1999).

Stötzel, G., Wengeler, M. (1995), Kontroverse Begriffe: Geschichte des öffentlichen Sprachgebrauchs in der Bundesrepublik Deutschland, de Gruyter, Berlin and New York.

Werneke, G. (1998), Politische Lexik in der Diskussion um die Europäische Währungsunion, untersucht an deutschen Pressetexten von September bis November 1997, M.A. thesis, University of Heidelberg.

Wurzel, W. U. (1994), Grammatisch initiierter Wandel, Universitätsverlag Dr. N. Brockmeyer, Bochum. 